\title{
Analysis of Healthy Lifestlye Behaviours of Hypertensive Patients
}

\author{
Mukadder Mollaoglu* and Gurcan Solmaz
}

Faculty of Health Sciences, Cumhuriyet University, Turkey

\begin{abstract}
Objective: The present study was conducted with the aim of determining the healthy lifestyle behaviours and affecting factors in hyptertensive patients.

Method: This descriptive study was carried out with 155 patients who were hospitalized at Internal Medicine and Endocrinology Clinics of Cumhuriyet University Hospital. Data were obtained using Personal Information Form (PIF) and Healthy Lifestyle Behaviours Scale (HLBS) and evaluated with number, percent, Mann Whitney U test, KruskalWallis test and qui square test.

Results:While the highest HLBS subscale scores were obtained from self-actualization, health responsibility, interpersonal relationships, stress management, the lowest scores were obtained from nutrition and physical activity subscales. Officers, married subjects and subjects with low income obtained high scores in self-actualization subscale; subjects who were 55 years old or above, graduates of intermediate school obtained high scores in health responsibility subscale; graduates of elemantary school and married subjects obtained high scores in physical activity subscale; male and married subjects obtained high scores in nutritional habits subscale and retired patients obtained high scores in total scale score $(p<0.05)$.
\end{abstract}

Conclusion: This research indicates that hypertensive patients do not follow healthy nutritional and physical activity principles and personal characteristics of patients affect healthy lifestyle behaviours.

Keywords: Hypertensive; Healthy lifestyle; Chronic diseases; Statistical

\section{Introduction}

Chronic diseases is the first leading cause of deaths worldwide. World Health Organization (WHO) stated in 2005 that chronic diseases is a neglected health problem which concern all humans. Hyptertension is the most common chronic disease [1]. Approximately $31.8 \%$ of Turkish population is known to have hyptertension [2]. Although there are approximately 70 million hyptertensive patients in USA, approximately half of the patients have a hyptertension under control [3]. According to three large scale studies conducted in our country, hyptertension prevalence was detected as $33.7 \%, 31.8 \%$ and $41.7 \%$ [2,4,5]. Ratio of the patients whose hyptertension is under control is about $30 \%$ and this ratio is under $10 \%$ in places where health services are not satisfactory [4]. However hyptertension is a preventable and controllable disease. Therefore hypertension development must be tried to be prevented with measures taken beginning from childhood [2]. Studies toward lifestyle changes and education programs should be performed. Giving instructions to the patients considering their sociodemographic features and disease- related features may create awareness and helps controlling the disease [6]. Blood pressure control and education for healthy lifestyle behaviours positively affect disease control $[7,8]$. Hypertensive patients should be instructed by health professionals in order to develop Healthy Lifestyle Behaviours (HLSB). Almost all of the patients $(92.5 \%)$ included in the study of Topuzoglu et al. were found not to be educated about hypertension [9]. Living conditions are as important as education about hypertension. In the research of Nidal and Eshah, working under heavy conditions, low income, living out of the city center were found to negatively affect health lifestyle behaviours [10]. Developing healthy lifestyle conditions is of great importance in chronic diseases like hypertension. This study was conducted with the aim of determining Healthy Lifestyle Behaviours (HLB) of hypertensive patients and affecting factors.

\section{Materials and Methods}

Study universe was composed of all hypetensive patients hospitalized at Internal Medicine and Endocrinology Clinics of Cumhuriyet University Universty Hospital. Sample was composed of 155 patients above 18 years who had been diagnosed with hypertension at least three months ago, who did not have disorders or disturbances which could affect cognitive functions and who were volunteer for participation.

Personal Information Form (PIF), Healthy Lifestyle Behaviours Scale (HLSBS) were used for data collection. Data were collected with face to face interview method after required explanation had been made by the researcher and through reviewing patient files.

Personal Information Form (PIF): This form which was prepared by the researchers under the light of literature [11-13] data included 35 questions about age, gender, marital status, sociodemographic features of the patient, disease and treatment and the clinic he was being hospitalized.

\section{Healthy Life-Style Behaviour Scale (HLSBS)}

HLSBS was developed by Walker, Sechrist and Pender in 1987 [14]. A study for the validity and reliability of the scale was made by Esin in 1997 [15] in Turkey and Cronbach Alpha value was found as 0.91. Questions in the scale are used to measure an individual's health-promoting behaviours in relation to his/her healthy life-style. Consisting of 48 items, the scale has 6 subgroups. Each subgroup may be used on its own independently. Subgroups include self-realization,

*Corresponding author: Mukadder Mollaoglu, Cumhuriyet University,Faculty of Health Sciences, 58140 Sivas, Turkey, Tel: 55562878 97; E-mail: mollaoglumukadder@gmail.com

Received July 04, 2014; Accepted July 15, 2014; Published July 25, 2014

Citation: Mollaoglu M, Solmaz G (2014) Analysis of Healthy Lifestlye Behaviours of Hypertensive Patients. Primary Health Care 4: 168. doi:10.4172/21671079.1000168

Copyright: (c) 2014 Mollaoglu M, et al. This is an open-access article distributed under the terms of the Creative Commons Attribution License, which permits unrestricted use, distribution, and reproduction in any medium, provided the original author and source are credited. 
health responsibility, exercise, nutrition, interpersonal support and stress management. Self-realization consists of 13 items with the lowest possible score of 13 and highest score of 52. Health responsibility consists of 10 items, with the lowest possible score of 10 and the highest score of 40 . Exercise consists of 5 items, with the lowest possible score of 5 and the highest score of 20 . Nutrition consists of 6 items, with the lowest possible score of 6 and the highest score of 24. Interpersonal support consists of 7 items, with the lowest possible score of 7 and the highest score of 28. Stress management consists of 7 items, with the lowest possible score of 7 and the highest score of 28 . The total score of the scale constitutes HLSB total point.

All items of the HLSB are positive. Marking is made on a 4- point Likert scale. 1 point is assigned to the answer "never", 2 points are assigned to the answer "sometimes", 3 points are assigned to the answer "frequently" and 4 points are assigned to the answer "regularly". The lowest score for the whole scale is 48 and the highest score is 192. Higher scores obtained in the scale indicate that the individual applies stated health behaviours at a high level $[14,15]$.

\section{Ethical Considerations}

Institutional approval was obtained from Cumhuriyet University Medical Sciences Ethical Committee. Study aims, plans and benefits were explained to patients who met the study criteria. Patients were asked if they would voluntarily participate in the study and their written/oral consents were obtained. Confidentiality was maintained at all times.

\section{Data Analysis}

The research data were loaded on the Statistical Package for the Social Sciences (SPSS) for Windows program, version 14.0. Percentage calculation, mean, test of significance between two means, qui-square test, one way analysis of variance, Mann-Whitney - $U$ test and Kruskal Wallis test were used in the analysis of the data. The data were evaluated in tables taking arithmetic means and standard deviation at 0.05 .

\section{Results}

While mean age of the patients is $56,45 \pm 7,98$ years, $72.3 \%$ of the patients are women, more than half $(58.1 \%)$ are housewives, $27.7 \%$ are retired, remaining are unemployed and officers, 59.4\% are married, $53.5 \%$ are only literate, $77.4 \%$ have low income. Mean duration of disease was found as 3.73 years (SD:1.07) (Table 1). When patients were questioned about controls of blood pressure and hypertension treatment, $78.1 \%$ of the patients stated that they did not go controls for blood pressure and hypertension treatment. When the habit of eating salt was analysed, almost all of them stated that they ate their meals with litte salt or normal amount of salt. When patients were questioned about alternative ways for treatment, $75.5 \%$ stated that they consumed lemon for reduction of blood pressure. More than half of the patients stated that they did not do physical exercises.

When patients were analysed for HLSB subscale scores, the highest scores were seen to be obtained from self actualization, health responsibility, interpersonal relationships, stress management subscales and the lowest score was seen to be obtained from nutritional habits and physical activity subscale (Table 2 ).

Health responsibility subscale score of the patients 55 years and above was found to be greater than that of the patients 55 years and

\begin{tabular}{|c|c|}
\hline Gender & n \% \\
\hline Male & $43 \quad(27.7)$ \\
\hline Female & 112 (72.3) \\
\hline \multicolumn{2}{|l|}{ Age (years) } \\
\hline$<55$ & $66(42.6)$ \\
\hline$\geq 55$ & $89(57.4)$ \\
\hline$x \pm S S$ & $56,45 \pm 7.98$ \\
\hline Min- max & $39-78$ \\
\hline $\begin{array}{l}\text { Occupation } \\
\text { Housewifes }\end{array}$ & $90(58.1)$ \\
\hline Retired & $43(27.7)$ \\
\hline Unemployed & $15(9.7)$ \\
\hline Officer & $7 \quad(4.5)$ \\
\hline \multicolumn{2}{|l|}{ Marital status } \\
\hline Married & $92(59.4)$ \\
\hline Single & $63(40.6)$ \\
\hline \multicolumn{2}{|l|}{ Education level } \\
\hline Literate & $83(53.5)$ \\
\hline Elementary & $50(32.3)$ \\
\hline Junior high school & $22(14.2)$ \\
\hline \multicolumn{2}{|l|}{ Income level } \\
\hline Low & $120(77.4)$ \\
\hline High & $35(22.6)$ \\
\hline \multicolumn{2}{|c|}{$\begin{array}{l}\text { Controls for blood pressure and hypertension } \\
\text { treatment }\end{array}$} \\
\hline Yes & $34(21.9)$ \\
\hline No & $121(78.1)$ \\
\hline \multicolumn{2}{|l|}{ The habit of eating salt } \\
\hline Litte salt or normal amount of salt & $153(98.7)$ \\
\hline Very salt & $2(1.3)$ \\
\hline $\begin{array}{l}\text { Alternative methods are used fo } \\
\text { pressure } \\
\text { Consuming garlic }\end{array}$ & $38(24.5)$ \\
\hline Consuming lemon & $117(75.5)$ \\
\hline \multicolumn{2}{|l|}{ Making physical activity status } \\
\hline No & $92(59.4)$ \\
\hline Yes & $63(40.6)$ \\
\hline
\end{tabular}

Table 1: Patients Characteristics.

\begin{tabular}{|l|c|c|}
\hline HLSB subgroup scores & $\mathrm{X} \pm \mathrm{SS}$ & Min-Max Values \\
\hline Self-realization & $37.43 \pm 7.13$ & $13.00-52.00$ \\
\hline Health responsibility & $28.83 \pm 5.40$ & $10.00-40.00$ \\
\hline Exercise & $15.55 \pm 2.01$ & $5.00-20.00$ \\
\hline Nutrition & $17.81 \pm 2.50$ & $6.00-24.00$ \\
\hline Interpersonal support & $19.43 \pm 2.96$ & $7.00-28.00$ \\
\hline Stress management & $19.08 \pm 3.46$ & $7.00-28.00$ \\
\hline HLSB Total & $137.59 \pm 11.94$ & $48.00-192.00$ \\
\hline
\end{tabular}

Table 2: Distribution of the mean scores of the patients HLSB.

below $(\mathrm{p}<0.05)$. Nutritional habits subscale score of male patients was found to be greater than that of females. While self-actualization, physical activity, nutritional habits subscale scores and total scale scores of married patients were found to be greater than those of singles, health responsbility and interpersonal relationships subscale scores of singles were found to be greater. While health responsibility subscale score of gradutaes of intermediate school was found to be greater than that of graduates of elemantary school and literates, physical activity subscale score of graduates of elemantary school was found to be greater than that of graduates of intermediate school and literates. While selfactualization subscale score of officers was found to be greater than that 
Citation: Mollaoglu M, Solmaz G (2014) Analysis of Healthy Lifestlye Behaviours of Hypertensive Patients. Primary Health Care 4: 168. doi:10.4172/2167-1079.1000168

Page 3 of 4

\begin{tabular}{|c|c|c|c|c|c|c|c|}
\hline & Self-realization & Health responsibility & Exercise & Nutrition & Interpersoal support & Stress management & HLSB Total Score \\
\hline Age $<55$ & $38.20 \pm 7.51$ & $28.74 \pm 6.37$ & $15.77 \pm 2.14$ & $17.98 \pm 2.62$ & $19.23 \pm 3.19$ & $19.11 \pm 3.84$ & $137.91 \pm 12.72$ \\
\hline$\geq 55$ & $\begin{array}{c}36.85 \pm 6.82 \\
p>0.05\end{array}$ & $\begin{array}{c}28.89 \pm 4.58 \\
p<0.05\end{array}$ & $\begin{array}{c}15.38 \pm 1.91 \\
p>0.05\end{array}$ & $\begin{array}{c}17.69 \pm 2.42 \\
p>0.05\end{array}$ & $\begin{array}{c}19.57 \pm 2.78 \\
p>0.05\end{array}$ & $\begin{array}{c}19.06 \pm 3.19 \\
p>0.05\end{array}$ & $\begin{array}{c}137.36 \pm 11.45 \\
p>0.05\end{array}$ \\
\hline \multicolumn{8}{|l|}{ Gender } \\
\hline Male & $39.63 \pm 6.64$ & $30.51 \pm 4.27$ & $16.07 \pm 1.94$ & $17.91 \pm 2.74$ & $19.60 \pm 2.70$ & $19.21 \pm 3.09$ & $142.56 \pm 12.35$ \\
\hline Female & $\begin{array}{c}36.58 \pm 7.16 \\
p>0.05\end{array}$ & $\begin{array}{c}28.18 \pm 5.66 \\
p>0.05\end{array}$ & $\begin{array}{c}15.35 \pm 2.01 \\
p>0.05\end{array}$ & $\begin{array}{c}17.78 \pm 2.42 \\
p<0.05\end{array}$ & $\begin{array}{c}19.36 \pm 3.06 \\
p>0.05\end{array}$ & $\begin{array}{c}19.03 \pm 3.62 \\
p>0.05\end{array}$ & $\begin{array}{c}135.69 \pm 11.31 \\
\mathbf{p}<0.05\end{array}$ \\
\hline \multicolumn{8}{|l|}{ Marital status } \\
\hline Married & $37.59 \pm 6.79$ & $28.78 \pm 5.38$ & $15.71 \pm 1.97$ & $17.91 \pm 2.39$ & $19.24 \pm 3.00$ & $18.79 \pm 3.55$ & $137.77 \pm 11.42$ \\
\hline Single & $\begin{array}{c}37.19 \pm 7.65 \\
p>0.05\end{array}$ & $\begin{array}{c}28.89 \pm 5.47 \\
p>0.05\end{array}$ & $\begin{array}{c}15.32 \pm 2.07 \\
p>0.05\end{array}$ & $\begin{array}{c}17.67 \pm 2.68 \\
p>0.05\end{array}$ & $\begin{array}{c}19.70 \pm 2.89 \\
p>0.05\end{array}$ & $\begin{array}{c}19.49 \pm 3.34 \\
p>0.05\end{array}$ & $\begin{array}{c}137.33 \pm 12.81 \\
p>0.05\end{array}$ \\
\hline \multicolumn{8}{|l|}{ Education level } \\
\hline Literate & $37.11 \pm 6.63$ & $28.67 \pm 5.20$ & $15.07 \pm 1.89$ & $17.51 \pm 2.33$ & $19.71 \pm 2.95$ & $19.22 \pm 3.39$ & $137.00 \pm 10.75$ \\
\hline Elementary & $37.64 \pm 7.10$ & $27.84 \pm 5.49$ & $16.12 \pm 1.97$ & $18.42 \pm 2.58$ & $19.04 \pm 3.06$ & $18.80 \pm 3.68$ & $137.28 \pm 12.27$ \\
\hline Junior high school & $\begin{array}{c}38.14 \pm 9.07 \\
p>0.05\end{array}$ & $\begin{array}{c}31.64 \pm 5.19 \\
p<0.05\end{array}$ & $\begin{array}{c}15.55 \pm 2.01 \\
\mathbf{p}<0.05\end{array}$ & $\begin{array}{c}17.59 \pm 2.84 \\
p>0.05\end{array}$ & $\begin{array}{c}19.23 \pm 2.75 \\
p>0.05\end{array}$ & $\begin{array}{c}19.08 \pm 3.47 \\
p>0.05\end{array}$ & $\begin{array}{c}140.55 \pm 15.40 \\
p>0.05\end{array}$ \\
\hline \multicolumn{8}{|l|}{ Occupation } \\
\hline Housewifes & $36.26 \pm 7.00$ & $28.54 \pm 5.49$ & $15.27 \pm 1.97$ & $17.68 \pm 2.32$ & $19.23 \pm 3.10$ & $19.22 \pm 3.41$ & $135.68 \pm 10.68$ \\
\hline Retired & $39.77 \pm 7.27$ & $30.23 \pm 4.82$ & $16.14 \pm 2.07$ & $18.19 \pm 2.80$ & $19.72 \pm 2.52$ & $19.37 \pm 3.18$ & $142.81 \pm 12.19$ \\
\hline Officer & $40.29 \pm 7.25$ & $29.57 \pm 1.98$ & $15.43 \pm 2.29$ & $17.00 \pm 2.30$ & $21.86 \pm 2.19$ & $19.29 \pm 5.05$ & $142.00 \pm 16.72$ \\
\hline Unemployed & $\begin{array}{c}36.40 \pm 5.96 \\
\mathbf{p}<0.05\end{array}$ & $\begin{array}{c}26.13 \pm 6.54 \\
p>0.05\end{array}$ & $\begin{array}{c}15.60 \pm 1.72 \\
p>0.05\end{array}$ & $\begin{array}{c}17.93 \pm 2.86 \\
p>0.05\end{array}$ & $\begin{array}{c}18.60 \pm 3.13 \\
p>0.05\end{array}$ & $\begin{array}{c}17.27 \pm 3.63 \\
p>0.05\end{array}$ & $\begin{array}{c}132.07 \pm 11.67 \\
\mathbf{p}<0.05\end{array}$ \\
\hline \multicolumn{8}{|l|}{ Income level } \\
\hline Low & $39.32 \pm 5.82$ & $28.88 \pm 4.96$ & $15.49 \pm 1.79$ & $17.76 \pm 2.71$ & $19.51 \pm 3.35$ & $18.93 \pm 3.63$ & $139.29 \pm 12.17$ \\
\hline High & $\begin{array}{c}36.75 \pm 7.45 \\
p<0.05\end{array}$ & $\begin{array}{c}28.81 \pm 5.57 \\
p>0.05\end{array}$ & $\begin{array}{c}15.57 \pm 2.09 \\
p>0.05\end{array}$ & $\begin{array}{c}17.83 \pm 2.44 \\
p>0.05\end{array}$ & $\begin{array}{c}19.39 \pm 2.82 \\
p>0.05\end{array}$ & $\begin{array}{c}19.13 \pm 3.43 \\
p>0.05\end{array}$ & $\begin{array}{c}136.98 \pm 11.89 \\
p>0.05\end{array}$ \\
\hline
\end{tabular}

Table 3: Comparison of average score of HLSB Subgroups according to personal characteristics of patients.

of housewives, retired patients and unemployed patients, total score of retired patients was found to be greater than that of other occupational groups. Self-actualization subscale score of patients with low income was found to be greater than that of high income (Table 3).

\section{Discussion}

Mean HLBS score of hypertensive patients is $137,59 \pm 11,94$ and this value is above the mean score. This condition indicates that hypertensive patients adopt health promotion behaviours. Similar results were obtained also from another study [6].

While the highest scores were obtained from self-actualization, health responsibility, interpersonal relationships and stress management, the lowest parameters were found to be nutrition and physical activity. The lowest mean score was found to belong to physical activity in the study conducted with patients with heart diseases and health professionals $[6,13,16,17]$. These findings suggest that physical activity habit is low in our country. On the other hand, hypertension development risk is $20-50 \%$ greater among individuals who live a sedentary life compared to the ones who do regular physical activity. Systolic blood pressure declines $4-8 \mathrm{mmHg}$ in hypertensive patients who regularly do physical activity [18]. Risk facors for heart diseases were analysed in Turkey and Germany in EUROASPIRE III trial. The most important risk factor was found as sedentary lifestyle in both countries [19].

Health responsibility which implies one's being responsible for his health and admitting to health professionals when required was found greater in advanced age patients compared to the younger. Health promotion behaviours included in health promotion model are affected from situational factors [20]. Environment of the individual and share with people may influence health promotion. Advanced aged people's frequently sharing their life experiences may probably enable increased awareness about diseases. In a study investigating social relations of individuals living in nursing home, friend support and sharing life experience were found greater than other social support fields [21].

In our study, male patients were found to have more healthier eating habits than females. This result is considered to be related with male patients' having a higher educational level. Therefore influence of healthy nutrition on healthy life style should be addressed in education programs especially toward women. In the study of Vançelik et al. carried out with university students, mean score of eating habit was found statistically significantly greater in males than females [22]. Similar results were also obtained in another study [6].

In the study, marital status was found to be another factor affecting HLBS. Married patients were found to have healthier lifestyle behaviours than singles. They were found to be better especially in selfactualization, physical activity, eating habits. It is reported that married people's having a regular lifestyle, being supported financially and morally help them to gain healthy lifestyle behaviours [13].

While health responsibility subscale score of graduates of intermediate school was found to be greater than that of literates, physical activity subscale score of graduates of elementary school was found to be greater than that of graduates of intermediate school and literates. In previous studies, health responsibility subscale score was seen to increase as education level increased [13,16,23]. On the other hand, it is striking to find that physical activity subscale score of graduates of elementary school is grater than that of graduates of intermediate school while it is expected to find it greater than that of literates. Most of the women enrolled in the study are graduates of elementary school, housewives and unemployed and the results may be related with their having more time for physical activity. 
Citation: Mollaoglu M, Solmaz G (2014) Analysis of Healthy Lifestlye Behaviours of Hypertensive Patients. Primary Health Care 4: 168. doi:10.4172/2167-1079.1000168

Page 4 of 4

Self-actualization levels of officers were found greater than those of members of other occupational groups. Workig environment enables one's self-actualization. However retired patients' having healthier lifestyle behaviours is considered to be related with individuals' who are not in work life being able to spare time for themselves and easily change lifestyle.

Self-actualization subscale score of patients with low income was found greater than those with high income. In the study of Johansson et al. HLBS scores were found to increase as socioeconomic status improved and this is conflicting with the results of our study [24]. Self-actualization is related with feeling morally good and sense of spirituality [12]. Therefore this is considered to be resulted from sociocultural characteristics of participants.

In conclusion, HLBS score of hypertensive patients is moderate and scores of physical activity and eating habits were found low. Officers, married patients and patients wth low income obtained high scores in self-actualization subscale; patients 55 years and above, graduates of intermediate school obtained high scores in health responsibility subscale; graduates of elemantary school, married patients obtained high scores in physical activity subscale; male and married patients obtained high scores in eating habits subscale and retired patients obtained high scores in total scale. According to these data, it may be recommended to arrange educations about the importance of healthy lifestyle behaviours, mainly nutrition and physical activity, on controlling hyptertension, to prepare and present programs toward changing knowledge, attitudes and skills of hypertensive patients who are in risk group but not having healthy life style behaviours.

\section{Acknowledgement}

We thank Dr. Ziynet Çınar, Department of Biostatistics, Cumhuriyet University for her help in analyzing the data.

\section{References}

1. World Health Organization (WHO) (2005) Preventing Chronic Diseases: A Vital Investment: Who Global Report. Geneva Switzerland.

2. Altun B, Arici M, NergizoAYlu G, Derici U, Karatan O, et al. (2005) Prevalence, awareness, treatment and control of hypertension in Turkey (the Patent study) in 2003. J Hypertens 23: 1817-1823.

3. Centers for Disease Control and Prevention (CDC) (2012) Vital signs: awareness and treatment of uncontrolled hypertension among adults--United States, 2003-2010. MMWR Morb Mortal Wkly Rep 61: 703-709.

4. Ongen Z (2005) Çözümü zor bir toplumsal sorun: hipertansiyon. Klinik Gelisim 18: 4-7.

5. Soydan I (2003) Hipertansiyon ile ilgili TEKHARF çalismasi verileri ve yorumu. In: Onat A Türk Eriskinlerde Kalp Sagligi (TEKHARF).Istanbul: Argos iletisim.

6. Küçükberber N, Ozdilli K, Yorulmaz H (2011) [Evaluation of factors affecting healthy life style behaviors and quality of life in patients with heart disease]. Anadolu Kardiyol Derg 11: 619-626.

7. Bell RA, Kravitz RL (2008) Physician counseling for hypertension: what do doctors really do? Patient Educ Couns 72: 115-121.

8. Dickson BK, Blackledge J, Hajjar IM (2006) The impact of lifestyle behavior on hypertension awareness, treatment, and control in a southeastern population.

\section{Am J Med Sci 332: 211-215.}

9. Topuzoglu A, Hidiroglu S, Önsüz MF, Polat G (2011) Istanbul'da Bir Birinci Basamak Saglik Kurulusunda Kronik Hastaliklardan Korunmada Kaçirilmis Firsatlar. TSK Koruyucu Hekimlik Bülteni;10: 665-674.

10. Nidal F, Eshah NF (2011) Lifestyle And Health Promoting Behaviours In Jordanian Subjects Without Prior History Of Coronary Heart Disease. International Journal of Nursing Practice 17: 27-35.

11. Özkan S, Yilmaz E (2008) Hastanede Çalisan Hemsirelerin Saglikli Yasam Biçimi Davranislari. Firat Saglik Hizmetleri Dergisi 3: 89-104.

12. Tuygar SF (2009) Bagimlilarda Saglikli Yasam Biçimi Davranisi Gelistirme Egitiminin Beden Kitle Indeksi Üzerine Etkisi. Yüksek Lisans Tezi, Ege Üniversitesi Saglik Bilimleri Enstitüsü Psikiyatri Anabilim Dali Bagimlilik Danismanligi Programi, Izmir: 128-162.

13. Türkol E, Günes G (2012) Inönü Üniversitesi Tip Fakültesi Hastanesinde Îhtisas Yapan Asistanlarin Saglikli Yasam Biçimi Davranislari Inönü Üniversitesi Tip Fakültesi Dergisi 19: 159-166.

14. Walker SN, Sechrist KR, Pender NJ( 1987) The Health Promoting Lifestyle Profile Development And Psychometric Characteristics. Nursing Research 36 76-80.

15. EsinN (1997) Healthy lifestyle behaviors scale of adopted Turkish. Nursing Bulletin.

16. Özkan S, Yilmaz E (2008) Hastanede Çalisan Hemsirelerin Saglikli Yasam Biçimi Davranislari. Firat Saglik Hizmetleri Dergisi;3: 89-104.

17. Yalçinkaya M, Özer FG, Karamanoglu AY (2007) Saglik Çalisanlarinda Saglikl Yasam Biçimi Davranislarinin Degerlendirilmesi. TSK Koruyucu Hekimlik Bülteni 6: 409-420.

18. Öksüz E (2004) Hipertansiyonda Klinik Degerlendirme Ve llaç Disi Tedavi Degerlendirme Formu. Sürekli Tip Egitim Dergisi 13: 100-104

19. TokgÃzoÄŸlu L, Kaya EB, Erol C, Ergene O; EUROASPIRE III Turkey Study Group (2010) [EUROASPIRE III: a comparison between Turkey and Europe]. Turk Kardiyol Dern Ars 38: 164-172.

20. Palank CL (1991) Determinants of health-promotive behavior. A review of current research. Nurs Clin North Am 26: 815-832.

21. Aksüllü N, Dogan S (2004) Huzurevinde Ve Evde Yasayan Yaslilarda Algilanan Sosyal Destek Etkenleri Ile Depresyon Arasindaki lliski. Anadolu Psikiyatri Dergisi

22. Vançelik S, Önal SG, Güraksin A, Beyhun E (2007) Üniversite Ögrencilerinin Beslenme Bilgi Ve Aliskanliklari Ile Iliskili Faktörler TSK Koruyucu Hekimlik Bülteni 6: 242-248

23. Westin L, Carlsson R, Erhardt L, Cantor-Graae E, McNeil T (1999) Differences in quality of life in men and women with ischemic heart disease. A prospective controlled study. Scand Cardiovasc J 33: 160-165.

24. Johansson P, Dahlström U, Broström A (2006) Factors and interventions influencing health-related quality of life in patients with heart failure: a review of the literature. Eur J Cardiovasc Nurs 5: 5-15. 